Available online at

www.macvetrev.mk

Original Scientific Article

\title{
COMPARATIVE CLINICAL AND HAEMATOLOGICAL INVESTIGATIONS IN LACTATING COWS WITH SUBCLINICAL AND CLINICAL KETOSIS
}

\author{
Vania Marutsova ${ }^{1}$, Rumen Binev ${ }^{1}$, Plamen Marutsov ${ }^{2}$ \\ ${ }^{1}$ Department of Internal Diseases, Faculty of Veterinary Medicine, \\ Trakia University, Students' Campus, 6000 Stara Zagora, Bulgaria \\ ${ }^{2}$ Department of Veterinary Microbiology, Infectious and Parasitic Diseases, \\ Faculty of Veterinary Medicine, Trakia University, Students'Campus, \\ 6000 Stara Zagora, Bulgaria
}

Received 20 January 2015; Received in revised form 27 March 2015; Accepted 31 March 2015

\begin{abstract}
Ketosis of lactating cows is among the most common metabolic diseases in modern dairy farms. The economic importance of the disease is caused by the reduced milk yield and body weight loss, poor feed conversion, lower conception rates, culling and increased mortality of affected animals. In the present study, a total of 47 high-yielding dairy cows up to 45 days in milk (DIM) are included. All animals were submitted to physical examination wich included checking the rectal body temperature, heart rate, respiratory and rumen contraction rates, and inspection of visible mucous coats. The body condition was scored, and blood $\beta$-hydroxybutyrate (BHBA) concentrations were assayed. The cows were divided into 3 groups: first group (control) $(n=24)$ with blood $\beta$-hydroxybutyrate level $<1.2 \mathrm{mmol} / 1$, second group $(\mathrm{n}=15)$ with blood $\beta$-hydroxybutyrate between $1.2-2.6$ $\mathrm{mmol} / \mathrm{l}$ (subclinical ketosis) and third group $(\mathrm{n}=8)$ with blood $\beta$-hydroxybutyrate $>2.6 \mathrm{mmol} / \mathrm{l}$ (clinical ketosis). Whole blood samples were obtained and analyzed for Red Blood Cell (RBC, 10 12/1), Hemoglobin (HGB, g/l), Hematocrit (HCT, \%), Mean Corpuscular Volume (MCV, fl), Mean Corpuscular Hemoglobin ( $\mathrm{MCH}, \mathrm{pg}$ ), Mean Corpuscular Hemoglobin Concentration (MCHC, g/l), White Blood Cell (WBC, 10 $/ 1$ ), Lymphocytes (LYM, 10\%/1), Monocytes (MON, 10\%/1), Granulocytes (GRA, $10^{9} / 1$ ), Red Blood Distribution Width (RDW, \%), Red Blood Cell Distribution Width Absolute (RDWa, fl), Platelets (PLT, 10\%/l) and Mean Platelet Volume (MPV, fl). In this study, deviations in the clinical parameters in the control group and in those with subclinical ketosis were not identified. The cows from the third group (clinical ketosis) exhibited hypotonia, anorexia and body weight loss vs. control group. Hematological analysis showed leukocytosis and lymphocytosis in cows with subclinical ketosis vs. control group. In cows with clinical ketosis WBC counts decreased (leukopenia), while hemoglobin content and hematocrit values are higher vs. control group. Blood BHBA values are higher in both groups of ketotic cows vs. the control group. The other analyzed parameters (RBC, MCH, MCHC, MCV, RDW, RDWa, MON, GRA, PLT and MPV) were close to control values.
\end{abstract}

Key words: ketosis, hematological parameters, $\beta$-hydroxybutyrate, dairy cows

\section{INTRODUCTION}

Metabolic disorders in ruminants are most frequently found in the transition period from late pregnancy to early lactation, as the animal's body suffers substantial changes. During the pregnancy,

Corresponding author: Dr. Rumen Binev, PhD

E-mail address: binew@abv.bg

Present address: Department of Internal Medicine and Clinical

Toxicology, Faculty of Veterinary Medicine, Trakia University,

Stara Zagora, Bulgaria

Phone: 0035942699530

Copyright: (C) 2015 Marutsova V. This is an open-access article published under the terms of the Creative Commons Attribution License which permits unrestricted use, distribution, and reproduction in any medium, provided the original author and source are credited.

Competing Interests: The authors have declared that no competing interests exist.

Available Online First: 16 April 2015

http://dx.doi.org/10.14432/j.macvetrev.2015.04.042 the metabolism of cows is adapted for the developing embryo (1), while during the early lactation the metabolism follows the increased production of milk.

Ketosis occurs most commonly after calving during the $2^{\text {nd }}$ lactation (3-7 week postpartum) $(2,3)$ and considerably less afterwards (4). This period corresponds to an inadequate energy intake and increasing milk secretion, determining the occurrence of a negative energy balance (5).

Subclinical ketosis (SCK) is a pathological condition associated with an increased level of ketone bodies in the organism without symptoms for clinical ketosis (6). Health and economic consequences of subclinical ketosis are reduced milk yield $(7,31)$, reproductive disorders $(8)$, low 
insemination index (9), prolonged service period, clinical and subclinical mastitis (10), abomasal dislocation (11), and/or clinical ketosis (12).

The periparturient period with metabolic and hormonal changes, stress factors has a significant impact on the health of dairy cows and decreases the resistance to various infections (13). The period of negative energy balance is of critical for appearance of clinical and subclinical ketosis. The increased blood concentrations of non-esterified fatty acids (NEFA) or $\beta$-hydroxybutyrate (BHBA) correlate positively with disturbances in dairy cows' health, reproduction and milk yield during the postpartum period $(12,14)$.

Marked hyperketonaemia is manifested clinically with reduced appetite, rapid weight loss and reduced milk yield. Sometimes, the animals exhibit nervous signs as pica, biting and licking unusual object, blindness (15). The faeces is usually hard, dry and scanty. Sometimes very high blood BHBA concentrations, clear clinical signs of ketosis could be absent (16).

Determination of the Body Condition Score (BCS) provides available information for the body reserves, for the determination of how dairy cows are prepared for the period of negative energy balance, full of stress and inappropriate diet (17). It can be used as an indicator for potential health problems in dairy cows, sheep and goats. The changes in BCS suggest the presence of inadequate energy supply and occurrence of postpartum metabolic disorders (18). Literature data about BCS before calving shows wide variety: $\leq 3.0(19) ; 3.25$ (20) and 3.003.50 (5). It is demonstrated that cows with BCS before calving which is $>3.5$ has 2.5 times higher risk of developing type II ketosis (21).

Some hematological and biochemical parameters are indicators of physiological, nutritional, metabolic and clinical status of production animals, as an important part of health and welfare management (22). Several authors report that blood BHBA concentrations are a basic parameter for proper evaluation of ketosis, where BHBA is more stable than other ketone bodies (acetone and acetoacetate) $(16,23)$.

For diagnostic SCK in lactating cows, mainly 3 values of blood BHBA are noticed in the literature: more than $1.0 \mathrm{mmol} / \mathrm{l}(24,25)$, more than $1.2 \mathrm{mmol} / \mathrm{l}$ $7,26)$ and more than $1.4 \mathrm{mmol} / \mathrm{l}(12,16,27)$. If the blood BHBA is more than $1-1.4 \mathrm{mmol} / \mathrm{l}$, there is 3 times greater risk for dislocation of the abomasum and/or development of ketosis $(12,16,27)$. In our previous studies of goats with subclinical ketosis (28), blood BHBA concentrations between 0.8 and 160
$1.9 \mathrm{mmol} / \mathrm{l}$ were established between the $10^{\text {th }}$ and the $30^{\text {th }}$ day of lactation. This data is comparable with type I subclinical ketosis in dairy cows. Subclinical ketosis and type I clinical ketosis (CK) occur usually between the postpartum days 14-21 and 5-50, respectively (16). Type II clinical ketosis is generally present during the first 14 days after calving, but could be encountered in cows up to the $30^{\text {th }}$ day of lactation.

Blood BHBA values for clinical ketosis are: over $2.0 \mathrm{mmol} / \mathrm{l} \mathrm{(29)}$, over $2.6 \mathrm{mmol} / \mathrm{l}$ (30) and over $3.0 \mathrm{mmol} / \mathrm{l}$ (2). Blood BHBA concentrations $>3.0 \mathrm{mmol} / \mathrm{l}$ were established only in $20 \%$ of ketotic cows (14).

Considering the widespread occurrence of bovine ketosis at a global scale (31) and economic losses incurred by farmers, the early and accurate diagnosis is essential for prevention of this disease. On the other hand, it is known that circulating ketone bodies (acetone, acetoacetate and BHBA) have negative influence on all organs and physiological processes of the animal body. Alterations in blood biochemistry can be used for early diagnosis of metabolic diseases and taking preventive measures for herd health management and against economic losses in dairy production.

The aim of this study was to investigate changes in the clinical and hematological parameters in high-yielding cows suffering from subclinical and clinical ketosis.

\section{MATERIAL AND METHODS}

\section{Animals}

Studies were performed in dairy farms in the Republic of Bulgaria and Republic of Serbia between February and September 2014.

\section{Experimental design}

A total of 47 Holstein cows from $1^{\text {st }}$ to $4^{\text {th }}$ lactation were included in the study ( $\mathrm{n}=29$ from R. Bulgaria and $n=18$ from R. Serbia). Dairy cows were fed rations corresponding to the physiological state (lactation) of the studied groups. All cows were up to 45 days in milk (DIM). In this study, the blood BHBA threshold value for subclinical ketosis was set to $\geq 1.2 \mathrm{mmol} / \mathrm{l}$, and for clinical ketosis - to $\geq 2.6 \mathrm{mmol} / \mathrm{l}$. All cows were submitted to physical examination, body condition score evaluation and analysis of blood $\beta$-hydroxybutyrate concentrations.

Cows were divided into three groups:

- first group $(\mathrm{n}=24)$ with blood BHBA level $<1.2 \mathrm{mmol} / 1$ - control cows; 
- second group with blood BHBA between 1.2$2.6 \mathrm{mmol} / \mathrm{l}(\mathrm{n}=15)$ - cows with subclinical ketosis;

- third group with blood BHBA $>2.6 \mathrm{mmol} / \mathrm{l}$ $(\mathrm{n}=8)-$ cows with clinical ketosis.

\section{Clinical investigations}

All cows were submitted to examination of the rectal body temperature, heart rate, respiratory and rumen contraction rates, and visible mucous inspection using routine clinical diagnostic procedures.

\section{Body condition scoring}

Body condition scores were evaluated using a 5 -point scale (1.0-5.0, at intervals of 0.25$)$. The cows were scored visually by two investigators (32).

\section{Blood samples and analyses}

Blood samples were collected through puncture of the coccygeal vein using sterile $21 \mathrm{G}$ needles and vacutainers either anticoagulated with $\mathrm{K}_{2}$ EDTA $3 \mathrm{ml}$ or with gel and clot activator $-6 \mathrm{ml}$. (Biomed, Bulgaria). Samples were obtained in the morning before feeding.

Blood BHBA concentrations were determined immediately using a portable Xpress-I system (Nova Biomedical, UK). Samples for CBC analysis were transported and stored at $4{ }^{\circ} \mathrm{C}$. Analysis was performed within 2 hours after sampling. The following parameters were determined: Red Blood Cell (RBC, 10 12/l), Hemoglobin (HGB, g/l), Hematocrit (HCT, \%), Mean Corpuscular Volume $(\mathrm{MCV}, \mathrm{fl})$, Mean Corpuscular Hemoglobin ( $\mathrm{MCH}$, pg), Mean Corpuscular Hemoglobin Concentration (MCHC, g/l), White Blood Cell (WBC, 10\%/1), Lymphocytes (LYM, 109/1), Monocytes (MON, $10^{9} / 1$ ), Granulocytes (GRA, 10\%/l), Red Blood Distribution Width (RDW, \%), Red Blood Cell Distribution Width Absolute (RDWa, fl), Platelets
(PLT, 10 $/ 1$ ) and Mean Platelet Volume (MPV, fl). Hematological investigations were analyzed on an automated analyser Exigo EOS Vet (Boule Medical $\mathrm{AB}$, Sweden).

\section{Statistical analysis}

Statistical analysis was done with Statistica 6.0 (Windows) software, StatSoft, Inc. (USA, 1993) and ANOVA test. Results were presented as mean $(\mathrm{x}) \pm$ standard deviation (SD). The level of statistically significance was $\mathrm{p}<0.05$.

\section{RESULTS}

Values of physical examination of cows with SCK showed no statistically significant changes vs. control group. Cows with $\mathrm{CK}$, had a reduced average rumen contraction rate $(\mathrm{p}<0.05)$ : $7.6 \pm 0.02$ vs control values $(11.4 \pm 0.02)$. Data from physical examinations (rectal temperature, heart rate, respiratory rate, rumen contraction rate) are presented in Table 1.

There were no changes in both groups of ketotic cows where inspection was performed of the color of visible mucosae, swelling, discharges and coat.

Reduced rumen contraction rate (hypotonia) was recorded, cows with clinical ketosis also exhibited anorexia and body weight loss.

The results of blood $\beta$-hydroxybutyrate concentrations and BCS in all cows included in experiment are presented in Table 2. Cows from group 2 (SCK) and group 3 (CK) BHBA levels were higher $-1.57 \pm 0.55 \mathrm{mmol} / \mathrm{l}(\mathrm{p}<0.05)$ and $4.75 \pm 1.36 \mathrm{mmol} / \mathrm{l}$ $(\mathrm{p}<0.001)$ respectively, compared to cows from the control group - $0.30 \pm 0.16 \mathrm{mmol} / \mathrm{l}$.

Average BCS in control animals was $3.55 \pm 0.36$, in SCK cows $-3.25 \pm 0.27$ and in cows with clinical ketosis (group 3 ) $-2.51 \pm 0.31$.

Table 1. Clinical parameters of cows from the control group (Group 1), with subclinical ketosis (SCK) (Group 2) and clinical ketosis (CK) (Group 3)

\begin{tabular}{lccc}
\hline Parameters & $\begin{array}{c}\text { Group 1 } \\
(\mathbf{c o n t r o l , ~} \mathbf{n}=\mathbf{2 4})\end{array}$ & $\begin{array}{c}\text { Group 2 } \\
(\mathbf{S C K}, \mathbf{n}=\mathbf{1 5})\end{array}$ & $\begin{array}{c}\text { Group 3 } \\
(\mathbf{C K}, \mathbf{n}=\mathbf{8})\end{array}$ \\
\hline Temperature $\left({ }^{\circ} \mathbf{C}\right)$ & $38.3 \pm 0.01$ & $38.8 \pm 0.02$ & $38.4 \pm 0.01$ \\
Heart rate $\left(\mathbf{m i n}^{-1}\right)$ & $75.4 \pm 0.03$ & $76.6 \pm 0.01$ & $77.3 \pm 0.01$ \\
Respiratory rate $\left(\mathbf{m i n}^{-1}\right)$ & $19.1 \pm 0.01$ & $20.2 \pm 0.02$ & $20.4 \pm 0.03$ \\
Rumen contractions $\left(\mathbf{m i n}^{-5}\right)$ & $11.4 \pm 0.02$ & $9.7 \pm 0.01$ & $7.6 \pm 0.02^{1 \mathrm{a}}$ \\
\hline
\end{tabular}

Legend: ${ }^{a} p<0.05$; 1-vs control group; 2 -vs group 2; 3-vs group 3 
Marutsova V. et al.

Table 2. Average blood concentrations of $\beta$-hydroxybutyrate (BHBA) and body condition scores (BCS) in cows from the control group (Group 1), with subclinical ketosis (SCK) (Group 2) and clinical ketosis (CK) (Group 3)

\begin{tabular}{lccc}
\hline Parameters & $\begin{array}{c}\text { Group 1 } \\
(\text { control, } \mathbf{n = 2 4})\end{array}$ & $\begin{array}{c}\text { Group 2 } \\
(\mathbf{S C K}, \mathbf{n}=\mathbf{1 5})\end{array}$ & $\begin{array}{c}\text { Group 3 } \\
(\mathbf{C K}, \mathbf{n}=\mathbf{8})\end{array}$ \\
\hline BHBA (mmol/l) & $0.30 \pm 0.16$ & $1.57 \pm 0.55^{1 \mathrm{a}}$ & $4.75 \pm 1.36^{1 \mathrm{c}}$ \\
BCS & $3.55 \pm 0.36$ & $3.25 \pm 0.27$ & $2.51 \pm 0.31$ \\
\hline
\end{tabular}

Legend: ${ }^{a} p<0.05 ;{ }^{b} p<0.01 ;{ }^{c} p<0.001 ; 1$-vs. control group1; 2-vs. group 2; 3-vs. group 3

Data reflecting changes in hematological parameters of both study groups are presented in Table 3. Cows with CK had higher HGB and HCT values - $109.37 \pm 12.11 \mathrm{~g} / 1$ and $29.86 \pm 4.32 \%$ respectively, vs. healthy cows $(97.75 \pm 9.52 \mathrm{~g} / 1$ and $26.72 \pm 3.00 \% ; \mathrm{p}<0.05)$. Total $\mathrm{WBC}$ values in cows with CK (group 3) were lower $-6.57 \pm 2.59$ $\left(10^{9} / 1\right) \quad(\mathrm{p}<0.05)$ as compared with controls: $9.61 \pm 4.76\left(10^{9} / 1\right)$. Unexpectedly, higher WBC values were detected in cows with subclinical ketosis - $14.87 \pm 7.73\left(10^{9} / 1\right)(\mathrm{p}<0.05)$, than in the control cows $-9.61 \pm 4.76\left(10^{\%} / 1\right)$. In cows with SCK higher values were established of lymphocytes -
$8.25 \pm 0.84\left(10^{9} / 1\right)(\mathrm{p}<0.05)$ vs. control group $4.89 \pm 0.77\left(10^{9} / 1\right)$.

The other hematology parameters (RBC, $\mathrm{MCH}$, MCHC, MCV, RDW, RDWa, MON, GRA, PLT and MPV) were not significantly different than values in control animals.

\section{DISCUSSION}

This research confirmed that blood BHBA concentrations in cows with SCK is higher than $1.2 \mathrm{mmol} / \mathrm{l}$ and in cows with $\mathrm{CK}$ is higher than

Table 3. Hematological parameters in cows from the control group (Group 1), with subclinical ketosis (SCK) (Group 2) and clinical ketosis (CK) (Group 3)

\begin{tabular}{|c|c|c|c|}
\hline Parameters & $\begin{array}{c}\text { Group } 1 \\
\text { (control, } n=24)\end{array}$ & $\begin{array}{c}\text { Group } 2 \\
(\mathrm{SCK}, \mathrm{n}=15)\end{array}$ & $\begin{array}{c}\text { Group } 3 \\
(\mathrm{CK}, \mathrm{n}=8)\end{array}$ \\
\hline $\operatorname{RBC}\left(\times 10^{12} / \mathbf{l}\right)$ & $5.70 \pm 0.57$ & $5.75 \pm 0.67$ & $6.31 \pm 0.74$ \\
\hline HGB (g/l) & $97.75 \pm 9.52$ & $99.73 \pm 8.17$ & $109.37 \pm 12.11^{1 \mathrm{a}}$ \\
\hline HCT (\%) & $26.72 \pm 3.00$ & $27.18 \pm 2.55$ & $29.86 \pm 4.32^{1 \mathrm{a}}$ \\
\hline MCV (fl) & $46.76 \pm 3.72$ & $46.20 \pm 2.88$ & $48.15 \pm 5.71$ \\
\hline МCH (pg) & $17.06 \pm 1.06$ & $17.14 \pm 0.94$ & $17.97 \pm 1.26$ \\
\hline RDW (\%) & $21.79 \pm 2.54$ & $20.82 \pm 4.13$ & $21.45 \pm 1.85$ \\
\hline RDWa (fl) & $30.05 \pm 3.61$ & $29.03 \pm 1.37$ & $30.55 \pm 4.31$ \\
\hline MCHC (g/l) & $366.16 \pm 10.26$ & $367.66 \pm 7.07$ & $368.12 \pm 13.84$ \\
\hline WBC $\left(\times 10^{9} / 1\right)$ & $9.61 \pm 4.76$ & $14.87 \pm 7.73^{1 \mathrm{a}}$ & $6.57 \pm 2.59^{1 \mathrm{a}}$ \\
\hline LYM (x109/1) & $4.89 \pm 0.77$ & $8.25 \pm 0.84^{1 \mathrm{a}}$ & $3.66 \pm 0.22$ \\
\hline MON (x10'/l) & $0.82 \pm 0.10$ & $1.14 \pm 0.11$ & $0.57 \pm 0.02$ \\
\hline GRA (x10/l) & $3.80 \pm 0.77$ & $5.13 \pm 0.77$ & $2.44 \pm 0.15$ \\
\hline PLT (x10/l) & $354.62 \pm 98.45$ & $365.53 \pm 139.38$ & $397.87 \pm 126.19$ \\
\hline MPV(fl) & $6.44 \pm 0.93$ & $6.01 \pm 0.65$ & $6.40 \pm 0.85$ \\
\hline
\end{tabular}

Legend: ${ }^{a} p<0.05 ;{ }^{6} p<0.01 ;{ }^{c} p<0.001 ; 1$-vs control group1; 2-vs group 2; 3-vs group 3 
$2.6 \mathrm{mmol} / \mathrm{l}$, which are set as limited values for subclinical and clinical ketosis, respectively. Blood BHBA is an indicator of inappropriate oxidation of non-esterified fatty acids in the liver (33). It is used as early marker for detection of ketosis in ruminants $(16,23)$. Some researchers $(24,25)$ set a limit value $>1.0 \mathrm{mmol} / \mathrm{l}$, others $(12,16,27)$ over $1.4 \mathrm{mmol} / \mathrm{l}$, while in the present study value over $1.2 \mathrm{mmol} / \mathrm{l}$ is chosen as a limit of exhibited clinical sings (7, 26). Reduced blood glucose level and low insulin secretion are triggers for enhanced mobilization of lipids from the adipose tissue and deposition of triglycerides in the liver parenchyma and stimulation of ketogenesis (34).

Low values of BCS in cows with clinical ketosis correlated negatively with higher blood BHBA concentrations. Loss of appetite is a further reason for high blood ketone bodies concentrations. The weight loss until the $30^{\text {th }}$ day of lactation has a considerable impact on the risk for development of ketosis, dislocation of the abomasum, milk yield reduction, disturbance of the reproductive performance and early embryonic death (35). Other authors (36) found that there was no relationship between the weight loss during the lactation and the incidence of metabolic diseases. Excessive fat deposition in the dry period correlates with increased occurrence of clinical ketosis in cows after calving (37). Literature and these results confirmed that the BCS is an important data for nutrition management of dairy herd.

The results from the complete blood count showed increased hemoglobin and hematocrit values only in cows with clinical ketosis. We suggest that these changes were due to higher erythrocyte counts in cows from group 3, although the differences were not statistically significant. Most authors (38) suggest that clinical and subclinical ketosis is not accompanied by changes in RBC, hemoglobin and hematocrit. There is literature data (39) for lower hemoglobin level and RBC counts in ketotic cows, as in these cases the erythropaenia was accompanied by anisocytosis and poikilocytosis.

Statistically significant increase of WBC is reported in this research in cows with SCK. It could be assumed that higher leukocyte counts were related to the wide spread of bovine enzootic leucosis in Bulgaria (40), and to the fact that 2 of cows $(13.3 \%)$ presented signs of metritis. The leukocytosis in cows during the postpartum period is most commonly attributed to acute or chronic inflammations (mastitis, endometritis, metritis etc.) (22).

Reduction in WBC counts was shown in cows from group 3 (with clinical ketosis). Results in this investigation are in agreement with other reports $(41,42,43)$. Lower WBC counts are reported in cows with enhanced catabolism in the periparturient period and increased blood BHBA levels (44). High levels of ketone bodies inhibit the cell proliferation in bone tissue (42), the in vitro chemotaxis of leukocytes (43) and respiratory activity of polymorphonuclear leukocytes (41).

In this study, we found statistically significant changes in lymphocyte counts (lymphocytosis) in cows suffering from SCK. This is consistent with the increased neutrophil and lymphocyte counts reported in lactating cows in consequence to the enhanced lipomobilisation, ketogenesis and hypoglycemia (45). On the other hand, high neutrophil and lymphocyte counts could result from stress and accompanying levels of glucocorticoids (cortisol) (46). The distinct immunosuppressive effects of high ketone bodies concentrations (BHBA and acetoacetate) (47) and oestrogens (48) are also acknowledged.

\section{CONCLUSION}

Clinical and subclinical ketosis among dairy cows in the first 45 days after delivery is quite prevalent. In practice, early detection is useful for treatment and assurance of good milk yields. The blood parameters, especially BCS and blood BHBA are excellent parameters for the nutritional status and health of dairy cows and could be utilized as markers for timely detection of metabolic disorders in cattle. Identification of problems at the herd is a signal for correction of the diet, preventive supplementation with rapid sources of energy etc., in order to reduce economic losses. Changes in hematology have a limited diagnostic value in clinical and subclinical ketosis, but our results provoke interest for further studies to clarify their meaning.

\section{REFERENCES}

1. Bell, A.W. (1995). Regulation of organic nutrient metabolism during transition from late pregnancy to early lactation. J. Anim. Sci. 73, 2804-2819. PMid:8582872

2. Oetzel, G.R. (2004). Monitoring and testing dairy herds for metabolic disease. Vet. Clin. North Am. Food Anim. Pract. 20, 651-674. http://dx.doi.org/10.1016/j.cvfa.2004.06.006 PMid:15471629

3. Kirovski, D., Šamanc, H., Cernescu, H., Jovanović, M., Vujanac, I. (2008). Fatty liver incidence on dairy cow farms in Serbia and Romania. International Symposium New Researches in Biotechnology", Romania, Buchurest, November $20^{\text {th }}$ to $21^{\text {st }}$, Biotechnology, series F, special volume. 
4. Radostis, O.M., Gay, C.C., Blood, D.C., Hinchcliff, K.W. (2000). Ketosis of ruminants. In: Radostits OM, DC Blood and CC Gay (Eds). Veterinary medicine: A textbook of the diseases of cattle, sheep, pigs, goats and horses. (pp. 1452-1462). $9^{\text {th }}$ Edition. London: Sounders Company.

5. Nogalski, Z., Górak, E. (2008). Effects of the body condition of heifers at calving and at the first stage of lactation on milk performance. Med. Weter. 64, 322-326.

6. Duffield, T.F., Kelton, D.F., Leslie, K.E., Lissemore, K.D., Lumsden, J.H. (1997). Use of test day milk fat and milk protein to detect subclinical ketosis in dairy cattle in Ontario. Can. Vet. J. 38, 713-718. PMid:9360791 PMCid:PMC1576823

7. McArt, J.A., Nydam, D.V., Oetzel, G.R. (2013). Dry period and parturient predictors of early lactation hyperketonemia in dairy cattle. J. Dairy Sci. 96, 198-209.

http://dx.doi.org/10.3168/jds.2012-5681

PMid:23102961

8. Whitaker, D.A., Smith, E.J., da Rosa, G.O., Kelly, J.M. (1993). Some effects of nutrition and management on the fertility of dairy cattle. Vet. Rec. 133, 61-64. http://dx.doi.org/10.1136/vr.133.3.61 PMid:8212484

9. Walsh, R., LeBlanc, S., Duffield, T., Leslie, K. (2004). Retrospective analysis of the association between subclinical ketosis and conception failure in Ontario dairy herds. Proc. World Buiatrics Congress / Med. Vet. Quebec, 34-152.

10. Suriyasathaporn, W., Heuer, C., Noordhuizen-Stassen, E.N., Schukken, Y.H. (2000). Hyperketonemia and udder defense: a review. Vet. Res. 31, 397-412. http://dx.doi.org/10.1051/vetres:2000128 PMid:10958241

11. LeBlanc, S.J., Leslie, K.E., Duffield, T.F. (2005). Metabolic predictors of displaced abomasum in dairy cattle. J. Dairy Sci. 88, 159-170.

http://dx.doi.org/10.3168/jds.S0022-0302(05)72674-6

12. Duffield, T.F., Lissemore, K.D., McBride, B.W., Leslie, K.E. (2009). Impact of hyperketonemia in early lactation dairy cows on health and production. J. Dairy Sci. 92, 571-580.

http://dx.doi.org/10.3168/jds.2008-1507

PMid:19164667

13. Meglia, G.E., Johannisson, A., Petersson, L., Persson Waller, K. (2001). Changes in some blood micronutritiens, leukocytes and neutrophil expression of adhesion molecules in periparturient dairy cows. Acta Vet. Scand. 42, 139-150. http://dx.doi.org/10.1186/1751-0147-42-139 PMid:11455894 PMCid:PMC2202342
14. Ospina, P.A., Nydam, D.V., Stokol, T., Overton, T.R. (2010). Associations of elevated non-esterified fatty acids and $\beta$-hydroxybutyrate concentrations with early lactation reproductive performance and milk production in transition dairy cattle in the northeastern United States. J. Dairy Sci. 93, 1596-1603.

http://dx.doi.org/10.3168/jds.2009-2852 PMid:20338437

15. Hungerford, T.G. (1990). Diseases of cattle. In: Diseases of livestock, $9^{\text {th }}$ Edition (pp. 34-347).

16. Oetzel, G.R. (2007). Herd-level ketosis - diagnosis and risk factors. Preconference seminar 7C: Dairy herd problem investigation strategies: transition cow troubleshooting American association of bovine practitioners, $40^{\text {th }}$ Annual Conference, September 19, 2007 - Vancouver, BC, Canada

17. Waltner, S.S., McNamara, J.P., Hillers, J.K. (1993). Relationships of body condition score to production variables in high producing Holstein cows. J. Dairy Sci. 76, 3410-3419.

http://dx.doi.org/10.3168/jds.S0022-0302(93)77679-1

18. Bewley, J.M., Schutz, M.M. (2008). Review: An interdisciplinary review of body condition scoring for dairy cattle. Professional Animal Scientist 24, 507-529.

19. Garnsworthy, P. (2008). Influences of body condition on fertility and milk yield. In: Proc dairy cattle reproduction council convention, 63-72.

20. Skidmore,A.L., Peeters, K.A.M., Sniffen, C.J., Brand, A. (2001). Monitoring dry period management. In: Brand, A., Noordhuizen, J. P. T. M., Schukken, Y. H. (Eds.), Herd Health and Production Management in Dairy Practice. (pp. 171-201). Wageningen Press

21. Gillund, P., Reksen, O., Grohn, Y.T., Karlberg, K. (2001). Body condition related to ketosis and reproductive performance in Norwegian dairy cows. J. Dairy Sci. 84, 1390-1396. http://dx.doi.org/10.3168/jds.S0022-0302(01)70170-1

22. Găvan, C., Retea, C., Motorga, V. (2010). Changes in the hematological profile of Holstein primiparous in periparturient period and in early to mid-lactation. Animal Sciences and Biotechnologies 43, 244-246.

23. Duffield, T.F. (2004). Monitoring strategies for metabolic disease in transition dairy cows. IVIS, $23^{\text {rd }}$ WBC Congress, Québec, Canada.

24. Goldhawk, C., Chapinal, N., Veira, D.M., Weary, D.M., Keyserlingk, von M.A.G. (2009). Prepartum feeding behavior is an early indicator of subclinical ketosis. J. Dairy Sci. 92, 4971-4977. http://dx.doi.org/10.3168/jds.2009-2242 PMid:19762814 
25. Kinoshita, A., Wolf, C., Zeyner, A. (2010). Studies on the incidence of hyperketonemia with and without hyperbilirubinaemia in cows in MecklenburgVorpommern (in Germany) in the course of the year. Tieraerztliche Praxis 38, 7-15.

26. Seifi, H.A., LeBlanc, S.J., Leslie, K.E., Duffield, T.F. (2011). Metabolic predictors of post-partum disease and culling risk in dairy cattle. Vet. J. 188, 216-220. http://dx.doi.org/10.1016/j.tvj1.2010.04.007 PMid:20457532

27. Geishauser, T., Leslie, K., Tenhag, J., Bashiri, A. (2000). Evaluation of eight cowside ketone tests in milk for detection of subclinical ketosis in dairy cows. J. Dairy Sci. 83, 296-299.

28. Binev, R., Marutsova, V., Radev, V. (2014). Clinical and haematological studies on subclinical lactational ketosis in dairy goats. Agricultural Science and Technology 6, 427-430.

29. Andrews, A.H., Blowey, R.W., Boyd, H., Eddy, R.G. (2004). Bovine Medicine Diseases and Husbandry of Cattle. Second edition. USA: Blackwell Publishing Company.

30. González, F.D., Mui-o, R., Pereira, V., Campos, R., Benedito, J.L. (2011). Relationship among blood indicators of lipomobilization and hepatic function during early lactation in high-yielding dairy cows. J. Dairy Sci. 12, 251-255.

http://dx.doi.org/10.4142/jvs.2011.12.3.251

31. Suthar, V.S., Canelas-Raposo, J., Deniz, A., Heuwieser, W. (2013). Prevalence of subclinical ketosis and relationships with postpartum diseases in European dairy cows. J. Dairy Sci. 96, 2925-2938. http://dx.doi.org/10.3168/jds.2012-6035 PMid:23497997

32. Edmonson, A.J., Lean, I.J., Weaver, L.D., Farver, T., Webster, G. (1989). A body condition chart for Holstein dairy cows. J. Dairy Sci. 72, 68-78. http://dx.doi.org/10.3168/jds.S0022-0302(89)79081-0

33. LeBlanc, S. (2010). Monitoring metabolic health of dairy cattle in the transition period. J. Reprod. Dev. $56,29-35$.

http://dx.doi.org/10.1262/jrd.1056S29

34. Grummer, R.R. (1993). Etiology of lipid-related metabolic disorders in periparturient dairy cows. J. Dairy Sci. 76, 3882-3896.

http://dx.doi.org/10.3168/jds.S0022-0302(93)77729-2

35. López-Gatius, F., Santolaria, P., Yaniz, J., Rutllant, J., López-Béjar, M. (2002). Factors affecting pregnancy loss from gestation day 38 to 90 in lactating dairy cows from a single herd. Theriogenology 57, 1251-1261. http://dx.doi.org/10.1016/S0093-691X(01)00715-4
36. Ruegg, P.L., Milton, R.L. (1995). Body condition scores of Holstein cows on Prince Edward Island, Canada: relationship with yield, reproductive performance, and disease. J. Dairy Sci. 78, 552-564. http://dx.doi.org/10.3168/jds.S0022-0302(95)76666-8

37. Markusfeld, O., Galon, N., Ezra, E. (1997). Body condition score, health, yield and fertility in dairy cows. Vet. Rec. 141, 67-72.

http://dx.doi.org/10.1136/vr.141.3.67

PMid:9257435

38. Sahinduran, S., Sezer K., Buyukoglu T., Albay M.K., Karakurum M.C. (2010). Evaluation of some haematological and biochemical parameters before and after treatment in cows with ketosis and comparison of different treatment methods. J. Anim. Vet. Adv. 9, 266-271.

http://dx.doi.org/10.3923/javaa.2010.266.271

39. Belić, B., Cincović, M.R., Stojanović, D., Kovačević, Z., Vidović, B. (2010). Morphology of erythrocyte and ketosis in dairy cows with different body condition. Contemporary agriculture 59, 306-311.

40. Sandev, N., Ilieva, D., Sizov, I., Rusenova, N., Iliev, E. (2006). Prevalence of enzootic bovine leukosis in the Republic of Bulgaria in 1997-2004. Vet. Arhiv 76, 263-268.

41. Hoeben, D., Heyneman, R., Burvenich, C. (1997). Elevated levels of beta-hydroxybutyric acid in periparturient cows and in vitro effect on respiratory burst activity of bovine neutrophils. Vet. Immunol. Immunopathol. 58, 165-170. http://dx.doi.org/10.1016/S0165-2427(97)00031-7

42. Hoeben, D., Burvenich, C., Massart-Leen, A.M., Lenjou, M., Nijs, G., Van Bockstaele, D. (1999). In vitro effect of ketone bodies, glucocorticosteroids and bovine pregnancy-associated glycoprotein on cultures of bone marrow progenitor cells of cows and calves. Vet. Immunol. Immunopathol. 68, 229-240. http://dx.doi.org/10.1016/S0165-2427(99)00031-8

43. Suriyasathaporn, W., Daemen, A.J., NoordhuizenStassen, E.N., Dieleman, S.J., Nielen, M., Schukken, Y.H. (1999). Beta-hydroxybutyrate levels in peripheral blood and ketone bodies supplemented in culture media affect the in vitro chemotaxis of bovine leukocytes. Vet.Immunol. Immunopathol. 68, 177-186. http://dx.doi.org/10.1016/S0165-2427(99)00017-3

44. Cincović, R.M., Belić, B., Radojičić, B., Hristov, S., Đoković, R. (2012). Influence of lipolysis and ketogenesis to metabolic and hematological parameters in dairy cows during periparturient period. Acta Vet. 62, 429-444. http://dx.doi.org/10.2298/AVB1204429C 
45. Belić, B., Cincović, M. R., Krčmar, Lj., Vidović, B. (2011). Reference values and frequency distribution of hematological parameters in cows during lactation and in pregnancy. Contemporary agriculture 60, $145-151$.

46. Burton, J.L., Madsen, S.A., Chang, L.C., Weber, P.S., Buckham, K.R, Van Dorp, R., Hickey, M.C., Earley, B. (2005). Gene expression signatures in neutrophils exposed to glucocorticoids: A new paradigm to help explain "neutrophil dysfunction" in parturient dairy cows. Vet. Immunol. Immunopathol. 105, 197-219. http://dx.doi.org/10.1016/j.vetimm.2005.02.012 PMid:15808301
47. Hefnawy, A.E., Shousha, S., Youssef, S. (2011). Hematobiochemical profile of pregnant and experimentally pregnancy toxemic goats. J. Basic. Appl. Chem. 1, 65-69.

48. Wyle, F.A., Kent, J.R. (1977). Immunosuppression by sex steroid hormones. Clin. Exp. Immunol. 27, 407. PMid:862230 PMCid:PMC1540928 